\title{
Pengaruh Diversitas Gender Terhadap Pengungkapan Sustainability Development Goals
}

\author{
Dessy Noor Farida ${ }^{1}$ \\ ${ }^{1}$ Fakultas Ekonomi dan Bisnis Islam, UIN Walisongo \\ email: 'dessy_nf@walisongo.ac.id
}

\begin{abstract}
Public awareness of the environment will be increasingly damaged due to industrial activities of large companies, making the community need information about the extent to which the company is responsible for the damage. This ecological crisis is driving concern from various countries in the world by formulating a Sustainability Development Goals that are expected to improve the quality of human life. Representation of women in the leadership of a company can be one of the drivers of companies to be more concerned with voluntary disclosures. This research is a quantitative research that uses multiple linear regression with a sample of companies listed on the ISSI for 4 consecutive years. The results showed that the presence of women on the board of directors did not affect the disclosure of SDGs. Whereas the presence of women in the board of commissioners has a significant effect on the disclosure of SDGs. The influential control variables are only the size of the company, while the variables of profitability and leverage have no effect.
\end{abstract}

Keywords: Sustainability Development Goals (SDGs), Board of Directors, Board of Commissioners, Gender Diversity

\section{PENDAHULUAN}

Kesadaran manusia akan rusaknya lingkungan di sekitar mereka yang diakibatkan kegiatan industri perusahaan-perusahaan besar, menjadikan masyarakat menjadi lebih peduli terhadap informasi tentang sejauh mana perusahaan bertanggungjawab atas kerusakan tersebut. Dengan adanya kerusakan lingkungan akan menyebabkan komponen makhluk hidup dan komponen benda mati yang bermanfaat bagi makhluk hidup seperti air, udara dan tanah akan menjadi tidak seimbang, sehingga komponen tersebut tidak dapat lagi berfungsi sebagaimana mestinya.

Kerusakan lingkungan yang disebabkan oleh aktivitas manusia, di picu semakin pesatnya pertumbuhan penduduk dan industrialisasi yang digunakan untuk memenuhi kebutuhan manusia yang semakin bertambah. Industrialisasi yang dilakukan secara terus menerus menyebabkan dampak negativ terhadap lingkungan di sekitar mereka. Hal ini disebabkan karena banyak industry yang tidak memperhatikan keseimbangan ekosistem sehingga pencemaran lingkungan tidak bias dihindarkan.

Salah satu contoh pencemaran lingkungan yang terjadi di Indonesia yang dikarenakan kegiatan industry adalah pembuangan limbah industry-industri di Surabaya ke sungai yang berdampak pada kehidupan masyarakat. Akibatnya, air menjadi tercemar, dan kualitas air menjadi menurun. Hal ini mengakibatkan masalah baru yaitu timbulnya penyakit kulit yang menyerang masyarakat sekitar karena menggunakan air 
sungai tersebut.. Contoh kerusakan lingkungan lainnya adalah timbulnya lumpur lapindo dan pencemaran di Teluk Buyat.

Grafik diatas menunjukkan adanya peningkatan yang terus menerus kadar CO2 (Karbondioksida)pada lapisan atmosfer dari tahun 2011 sampai dengan Maret 2015. Peningkatan yang terjadi cukup okum, dari tahun 2011, dimana kadar karbondioksida berada di kisaran 390-an ppm menjadi sebesar 400 ppm lebih pada tahun 2015. Hal ini disebabkan karena banyaknya kegiatan rumah tangga dan industry yang menghasilkan limbah karbondioksida, sehingga semakin memperparah kondisi bumi dimasa yang akan okum. Selain itu, penggunaan bahan-bahan kimia menyebabkan pemanasan global, dan ini menyebabkan semakin menipisnya lapisan ozon. Hal ini juga ditandai dengan semakin banyak es yang mencair di belahan kutub utara dan kutub selatan bumi, serta semakin sedikitnya hutan tropis akibat dari penebangan pohon yang dtidak disertai dengan penanaman kembali.

Dengan adanya pencemaran lingkungan yang terjadi karena aktivitas industry, menyebabkan hilangnya kepercayaan masyarakat dan pemangku kepentingan terkait dengan bagaimana perusahaan mempertanggungjawabkan kerusakan yang telah terjadi. Stakeholder dan investor membutuhkan lebih banyak informasi terkait bagaimana perlakuan perusahaan terhadap lingkungannya. Sebagai tanggapannya, manajemen mengungkapkan informasi social dan lingkungan melalui laporan tahunan untuk memenuhi harapan dari para pemangku kepentingan.

Tujuan utama adanya pengungkapan yang dituangkan dalam laporan tahunan adalah untuk meningkatkan transparansi, akuntabilitas dan mengurangi biaya agensi serta mengurangi biaya informasi di pasar saham (Cormier, Ledoux, \& Magnan, 2011). Penelitian sebelumnya juga menemukan bukti bahwa pengungkapan yang di lakukan oleh perusahaan terkait kegiatan CSR-nya (Corporate Social Responsibility) telah mencerminkan kinerja perusahaan, kepercayaan dan reputasi perusahaan yang bersangkutan (Aguilera, Williams, Conley, \& Rupp, 2006).

Adanya krisis ekologi yang ditandai dengan pencemaran lingkungan, pemanasan global, perubahan iklim, dan kelangkaan sumber daya alam merupakan masalah lingkungan yang menyebabkan semakin tingginya kesadaran masyarakat terhadap pentingnya keberlanjutan lingkungan untuk kesejahteraan manusia. Hal ini yang mendasari dibentuknya konsep pembangunan berkelanjutan dalam SDGs, yang terdiri dari 3 pilar yaitu pilar ekonomi, social, okum dan tata kelola (BPS,2018).

Tujuan perusahaan salah satunya adalah keberlanjutan kegiatan operasional, oleh karena itu, selain keuntungan yang diharapkan oleh perusahaan dalam jangka panjang, maka kegiatan perusahaan harus sejalan dengan keadilan okum dan untuk melindungi lingkungan hidup di sekitarnya. Dengan adanya SDGs maka akan membantu perusahaan untuk menetapkan tujuan yang akan di capai, pengukuran kinerja, dan pengelolaan terhadap perubahan agar operasi mereka lebih berkelanjutan.

Dari penelitian yang dilakukan oleh PBB menunjukkan bahwa dari 1000-an CEO dari lebih 100 negara menyimpulkan bahwa sekitar 89\% CEO telah menyadari bahwa komitmen perusahaan terhadap SDGs dapat memberikan dampak pada industry mereka. Penelitian PWC pada tahun 2017, dari 470 perusahaan di 17 negara, menemukan bahwa 62\% perusahaan di dunia telah mencantumkan SDGs dalam laporan perusahaan.

Jurnal Akuntansi Indonesia 
Tetapi, hanya 37\% yang serius dalam menetapkan prioritas target SDGs yang akan menjadi sasaran perusahaan. Sedangkan sisanya, yaitu sebesar 63\% perusahaan tidak mencantumkan kaitan antara SDGs dengan target perusahaan pada laporan perusahaan. Sehingga dapat disimpulkan bahwa masih banyak perusahaan yang memandang SDGs sebagai suatu konsep, tanpa benar-benar ditautkan dengan target perusahaan (majalahakuntanindonesia, 2018).

Untuk mendukung SDGs, pemerintah Indonesia menerbitkan Peraturan Presiden (Pepres) No 59/2017 tentang Pelaksanaan Pencapaian Tujan Pembangunan Berkelanjutan. Namun, Pepres ini belum berjalan efektif. Hal ini ditunjukkan dengan adanya laporan SDSN (Sustainable Development Solution network), yang menunjukkan peringkat Indonesia yang mengalami penurunan, dari peringkat 98 di tahun 2016 menjadi peringkat ke 100 pada tahun 2017. Posisi Indonesia tertinggal dari Malaysia, Thailand, Singapura, Vietnam dan Filipina.

Dalam pelaksanaan SDGs, diharapkan semua elemen masyarakat dapat terlibat, sehingga tujuan-tujuan SDGs akan tercapa sesuai target. SDGs tidak mebedakan agama, suku, ras, maupun jenis kelamin. Semua berhak terlibat dan menikmati hasil pembangunan yang berkelanjutan. Sejak di adopsinya SDGs pada tahun 2015, keinginan untuk mencapai kesetaraan gender semakin kuat dari sebelumnya.

Dengan adanya tuntutan kesetaraan gender, hal ini menyebabkan banyak perusahaan yang memberikan kesempatan yang sama terhadap semua individu untuk menempati berbagai posisi penting, hal ini dapat dilihat dari semakin banyaknya wanita yang berada di level komisaris dan direksi. Pada umumnya wanita modern sangat sadar akan artinya pendidikan, sehingga mereka berhasil menempati posisi strategis dalam perusahaan. Wanita juga dinilai memiliki peran penting untuk mendorong peningkatan kinerja karena mereka memiliki daya okum yang tinggi, selain itu wanita sangat teliti dalam bekerja walaupun lebih mengandalkan perasaan di bandingkan logika (Hadya \& Susanto, 2018).

Keterlibatan perempuan di dalam kegiatan sosial dan ekonomi menjadi topik yang cukup menarik akhirakhir ini. Perempuan memiliki kesempatan yang sama dalam menduduki semua level di perusahaan. Baik tingkat terendah sampai dengan tingkat tertinggi. Mengutip dari penelitian yang dilakukan oleh (Mazaya, 2014) bahwa di dalam AI Qur'an perempuan mempunyai keleluasaan untuk memasuki semua sektor kehidupan masyarakat, termasuk dalam bidang politik dan ekonomi.

Peran perempuan dalam dewan direksi terhadap pengungkapan corporate social reporting perusahaan sudah banyak dilakukan. Dengan melakukan pengungkapan yang bersifat sukarela maka akan dapat meningkatkan hubungan perusahaan dengan pihak lain, diantaranya adalah investor, perbankan, konsumen, suplier dan pihak lain yang berkepentingan terhadap perusahaan. Dengan melakukan pengungkapan CSR perusahaan dapat mengurangi masalah keagenan. Penelitian yang dilakukan oleh Bear \& Post (2010) menemukan direksi perempuan lebih sensitif terkait dengan aktivitas CSR jika dibandingkan dengan laki-laki, hal ini disebabkan karena wanita lebih memiliki kecenderungan terkait dengan masalah sosial, pendidikan dan peraturan.

Adanya krisis ekologi, mendasari dibentuknya konsep pembangunan berkelanjutan dalam SDGs, yang terdiri dari 3 pilar yaitu pilar ekonomi, social, okum dan tata kelola. Penelitian terdahulu lebih banyak 
menghubungan keberadaan dewan direksi wanita terhadap pengungkapan Corporate Social Responsibility dan pengungkapan sukarela lainnya. Penelitian ini lebih berfokus pada pengungkapan perusahaan terhadap laporan pembangunan berkelanjutan (SDGs Reporting) yang belum banyak dilakukan oleh peneliti-peneliti sebelumnya.

\section{TINJAUAN PUSTAKA DAN PENGEMBANGAN HIPOTESIS}

\section{Teori Agensi}

Jensen \& Meckling (1976) dalam penelitiannya menyatakan bahwa hubungan keagenan adalah adanya kontrak atau perjanjian antara manajer (agen) dengan investor (principal). Perbedaan kepentingan antara investor dan manajer dapat terjadi ketika investor tidak memiliki kemudahan untuk mendapatkan informasi yang diinginkannya terkait dengan kinerja manajer. Karena informasi yang didapatkan investor tidak mencukupi, maka investor tidak pernah mengetahui bagaimana usaha manajer dalam memberikan kontribusi terhadap perusahaan. Hal yang demikian ini disebut sebagai asimetri informasi. Pemegang saham akan menginginkan mekanisme pengendalian untuk memonitor kinerja manajer, yaitu dengan cara adanya audit dari pihak eksternal dan pengungkapan yang bersifat sukarela (seperti pengungkapan CSR atau pengungkapan Sustainability report).

Keberadaan perempuan di jajaran direksi, akan dapat bertindak sebagai mekanisme pengawasan dan pengendalian kinerja dewan direksi (Ferreira, 2009). Perempuan dianggap bisa lebih independent di bandingkan laki-laki. Direktur wanita telah memperoleh pendidikan yang tinggi, sehingga bias diangap sebagai orang yang professional dan berpengalaman. Beberapa penelitian membuktikan bahwa pengaruh keberadaan dewan direksi perempuan telah terbukti pada keputusan perusahaan untuk menentukan kompensasi eksekutif, kebijakan deviden, nilai perusahaan dan pengungkapan CSR, dan lain sebagainya (Martínez et al., 2018).

Keterkaitan dewan direksi wanita dan pengungkapan didasari dengan teori agensi ini. Dalam teori ini menjelaskan bahwa keberadaan dewan direksi perempuan akan meningkatkan independensi dewan direksi sehingga akan mengurangi biaya agensi dan sebagai konsekuensinya akan terjadi peningkatan nilai perusahaan. Selain itu dewan direksi wanita memiliki tanggungjawab yang tinggi dalam proses pengambilan keputusan. Terkait dengan pelaporan sukarela, menurut teori keagenan pengungkapan ini di maksudkan untuk meningkatkan pengawasan terhadap pihak manajemen, perusahaan yang dengan sukarela melaporkan laporan CSR dalam laporan keberlanjutan tahunan perusahaan maka dianggap perusahaan tersebut lebih bertanggung jawab terhadap keadaan social. Dan hal ini dapat meningkatkan hubungan antara perusahaan dengan para pemangku kepentingan (kreditor, investor, pelanggan, pemaso dll), dan pada akhirnya hal ini dapat mengurangi masalah keagenan.

\section{Teori Stakeholder}

Teori Stakeholder yang dicetuskan oleh Freeman (1984) mendefiniskan pemangku kepentingan dalam suatu organisasi sebagai suatu kelompok atau perseorangan yang dapat mempengaruhi atau dipengaruhi 
oleh pencapaian tujuan organisasi. Dalam teori stakeholder, manajer harus mempertimbangkan kepentingan semua pemangku kepentingan perusahaan, bukan hanya pemegang saham saja tetapi pihak lain seperti kreditor, masyarakat, pemasok dan lain-lain. Pemangku kepentingan yang dimaksud juga bisa di sebut pihakpihak yang dapat mempengaruhi perusahaan dalam mencapai tujuan atau pihak yang dapat dipengaruhi dari pencapaian tujuan perusahaan. Hal ini tentunya tidak mudah bagi perusahaan untuk dapat memenuhi semua kepentingan banyak pihak yang berbeda-beda. Manajer harus dapat menjalin hubungan yang baik dengan berbagai pihak, sehingga dapat menumbuhkan loyalitas mereka terhadap perusahaan, sehingga nilai perusahaan dapat dicapai.

Dikutip dari penelitian yang dilakukan oleh Dallas (2002) perusahaan secara terus menerus melakukan perbaikan dalam lingkungan bisnisnya untuk dapat meningkatkan kreativitas dan kualitas pengambilan keputusan dengan salah satu caranya yaitu dengan menciptakan kelompok yang heterogen. Dengan adanya kelompok yang heterogen maka akan muncul beragam perspektif yang berbeda. Pemilihan direktur perempuan juga di dasari keinginan perusahaan untuk menunjukkan komitmennya kepada pemangku kepentingan terkait dengan kepedulian perusahaan terhadap golongan minoritas (wanita) di jajaran dewan direksi (Francoeur et al, 2008) dalam (Martínez et al., 2018).

Teori stakeholder juga dapat menjelaskan bahwa direktur wanita dalam suatu perusahaan dapat membuat dewan direksi menjadi lebih inovatif dan transparan sehingga dapat mendorong perusahaan melakukan perubahan yang berasal tuntutan dari luar, contohnya adalah pengungkapan sukarela (CSR atau SDGs Reporting). Mengutip dari hasil penelitian (Yasser, Al Mamun, \& Ahmed, 2017) mengungkapkan bahwa direktur wanita dapat mempengaruhi pelaporan CSR. Dari penelitian Hillman et al (2002) diketahui bahwa proporsi yang tinggi dari direktur wanita dalam dewan direksi akan memungkinkan perusahaan untuk menjamin terpenuhinya kepentingan para pemangku kepentingan.

Sedangkan penelitian yang dilakukan oleh De Celis et al, 2015 menemukan bahwa keberadaan direktur perempuan menerapkan upaya khusus agar perusahaan menjadi perusahaan yang lebih demokratis serta memiliki kepedulian social dan lingkungan. Hal ini dikarenakan direktur wanita lebih bertanggungjawab sehingga akan dapat mendorong perusahaan untuk mengungkapkan kegiatan CSR-nya.

\section{Sustainability Development Goal"s (SDGs)}

Sustainable Development Goals, yang selanjutnya akan di sebut SDGs dicanangkan oleh PBB (Perserikatan Bangsa - Bangsa) tahun 2015, dimana terdapat 17 item untuk dapat di capai pada tahun 2030. Acara ini diadakan untuk menaggulangu masalah kemiskinan, kesenjangan sosial dan perubahan iklim. Jika semua capaian SDGs dapat diraih, maka lingkungan diharapkan menjadi lebih baik bagi kehidupan masyarakat. Semua elemen masyarakat diharapkan dapat ikut berpartisipasi dalam memelihara lingkungan. Untuk mencapai SDGs maka sector swasta maupun sektor pemerintahan harus memasukkan unsur SDGs dalam strategi perusahaannya, yang diikuti dengan implementasi dari strategi tersebut.

SDGs tidak dapat dicapai tanpa kerjasama antara pemerintah, sector swasta dan organisasi public serta masyarakat. Pemerintah memiliki tanggungjawab yang besar untuk pencapaian tujuan pembangunan 
berkelanjutan, sehingga dalam upaya mencapai tujuan tersebut pemerintah menetapkan aturan melalui Undang-Undang atau peraturan. Salah satu caranya adalah membuat aturan untuk sector swasta yang akan listing di bursa efek untuk memenuhi beberapa persyaratan, yang salah satunya adalah perusahaan yang listing dianjurkan untuk membuat pengungkapan terkait SDGs. Hal ini merupakan salah satu yang harus dipertimbangkan oleh investor dalam pengambilan keputusannya.

Dalam pencapaian SDGs, diperlukan adanya mekanisme yang tata kelola yang baik dalam perusahaan, salah satunya adalah berfungsinya pengawasan dan adanya mekanisme penilaian kualitas yang baik (Adams, 2017). Perusahaan yang mengintegrasikan SDGs dalam strategi perusahaannya akan dapat meningkatkan investasi dari pemegang saham lebih banyak dan dapat memaksimalkan nilai perusahaan. Selain itu penerapan SDGs dalam strategi perusahaan dapat mengurangi resiko, mengidentifikasi peluang dan memberikan keuntungan jangka panjang (Adams, 2017).

Penyusunan laporan keberlanjutan di Indonesia masih bersifat tidak wajib. Pengecualian untuk perusahaan-perusahaan yang mneghasilkan polusi terbesar, wajib untuk melaporkan pertanggungjawaban lingkungannya, seperti perusahaan pertambangan, kosntruksi dll. Pemerintah memiliki peran yang cukup besar dalam menjadikan laoran keberlanjutan sebagai laporan yang nantinya bersifat mandatory melalui instrument regulasi. OJK (Otoritas Jasa Keuangan) sedang mempersiapkan regulasi yang mewajibkan emiten melaporkan aspek ekonomi, social dan lingkungannya. Ketika laporan keberlanjutan menjadi mandatory maka perusahaan akan menjadi lebih akuntanbel dan lebih transparan. Sehingga dengan demikian, para pemangku kepentingan akan merasa lebih percaya kepada perusahaan dan hal ini dapat meningkkatkan nilai perusahaan.

Dengan adanya pelaporan pembangunan yang berkelanjutan akan menambah akuntabilitas perusahaan. Hal ini menjadi peluang untuk membangun kembali kepercayaan dari para stakeholder terhadap perusahaan. Pelaporan pembangunan berkelanjutan juga mendorong perusahaan untuk berartisipasi dalam kemajuan dan dapat digunakan untuk melaporkan kontribusi perusahaan dalam pencapaian SDGs dan menyajikan informasi yang lebih bermanfaat untuk stakeholder perusahaan.

\section{Pengungkapan SDGs dan Direksi Wanita}

Penelitian terkait dengan representasi wanita dalam kepemimpinan suatu perusahaan dengan pengungkapan sudah cukup banyak dilakukan. Dengan menggunakan Resource Based Views (RBV) telah dirumuskan suatu teori bahwa suatu perusahaan akan memiliki competitive advantage ketika perusahaaan memiliki sumber daya manusia yang unggul. Penggabungan sumber daya wanita dan laki-laki dianggap merupakan perpaduan sumber daya perusahaan yang utama karena mereka memiliki bakat yang berbeda dalam tanggungjawab perusahaan (Martínez, Oms, \& Olcina-Sempere, 2018.

Seperti dikutip dalam penelitian yang telah dilakukan oleh Terjesen \& Singh, (2008) menyatakan bahwa keahlian dan reputasi anggota dewan dapat mendorong untuk meningkatkan keuntungan perusahaan. Terkait dengan representasi wanita dalam anggota dewan, dalam penelitian yang dilakukan oleh Solimene, Coluccia, \& Fontana (2017) menemukan bahwa terjadi peningkatan jumlah dewan direksi wanita di perusahaan Negara 
Spanyol dari 6,61\% pada tahun 2009 menjadi 22,69\% pada tahun 2014. Begitu juga terjadi peningkatan di negara-negara lain diantaranya perusahaan di Amerika Latin, Portugal, Peru dan Meksiko. Hal ini menunjukkan bahwa wanita mampu memanfaatkan peluang untuk mendapatkan pendidikan, sehingga mereka dapat berperan baik dalam bidang ekonomi maupun sosial politik (Martínez et al., 2018) hampir 90\% perusahaan yang listing di New Zealand Stock Exchange tidak memiliki perwakilan direktur wanita di dewan direksi.

Berdasarkan penelitian yang dilakukan oleh Seierstad et al (2017) peran direktur wanita dalam dewan direksi adalah sangat penting, hal ini disebabkan karena 2 alasan, yaitu bisnis dan keadilan. Alasan yang pertama didasarkan pada premis bahwa adanya wanita dalam dewan direksi dapat meningkatkan kinerja. Sedangkan alasan yang kedua berfokus pada adanya kesetaraan gender antara direksi wanita dan direksi lakilaki.

Menurut Johston dan Packer (1987) dalam Martinez et al (2018) pada tahun 1980-an, keberadaan wanita dan etnis minoritas dalam manajemen di perusahaan Amerika Serikat sangat minim sekali, dan ini menjadi masalah manajemen. Hal ini berubah ketika perusahaan mulai memberikan kesempatan kepada wanita untuk menduduki wilayah manajemen dengan anggapan bahwa wanita memiliki kemampuan yang dapat meningkatkan efisiensi ekonomi dan meningkatkan keunggulan kompetitif pada perusahaan.

Beberapa penelitian, dalam Martínez et al (2018) menunjukkan bahwa direktur wanita memiliki ketrampilan yang lebih baik dibandingkan direktur laki-laki, dan hal ini mengakibatkan meningkatnya kinerja organisasi dengan cara keberagaman dewan direksi membantu dalam memahami volatilitas pasar tenaga kerja yang dapat menyebabkan semakin luasnya demografi untuk menembus pasar dan menarik pelanggan serta pemasok potensial (Robinson \& Dechant, 1997). Cara yang kedua direktur wanita dapat menciptakan suasana yang terbuka dan relaxdan dapat meningkatkan kreativitas serta inovasi (Huse, Nielsen, Marie, \& Fafo, 2008). Cara yang ketiga adalah direktur wanita membantu menyelesaikan masalah perusahaan dengan menciptakan heterogenitas dewan direksi dalam pembuatan keputusan, yang menyebabkan perusahaan harus mengevaluasi banyak alternative dan lebih berhati-hari dalam mempertimbangkan konsekuensi dari keputusan tersebut (carter, et al, 2003)but the consequences of doing so are inconsistent and could decrease firm performance and economies. This paper shed light on this diversity at board level topic by conceptualizing the relationships as firm value and diverse board. Reasonable theoretical arguments drawn from Upperechelon theory and agency theory suggest that board characteristics (gender, ethnic and age diversity.

\section{Pengembangan Hipotesis}

\section{Pengaruh keberadaan dewan direksi wanita dalam pengungkapan laporan sustainability development goals (SDGs).}

Di Indonesia, management board (dewan direksi) diketuai oleh presiden direktur atau direktur utama. Dewan direksi merupakan pihak yang berwenang dan bertanggungjawab penuh atas kepengurusan perseroan untuk kepentingan perseroan sesuai dengan maksud dan tujuan perseroan. Dalam UU no 40/2007 pasal 97 menyatakan bahwa direksi bertanggungjawab penuh terhadap pengurusan perusahaan untuk kepentingan dan tujuan perusahaan.

Pengaruh Diversitas Gender Terhadap Pengungkapan Sustainability Development Goals 
Semakin meningkatnya perhatian terhadap kinerja perusahaan untuk meningkatkan kesejahteraan pemangku kepentingan, hal ini menyebabkan semakin tinggi pula kebutuhan akan pengungkapan pertanggungjawaban social perusahaan, di satu sisi pengungkapan tersebut di maksudkan untuk menanggapi masalah social yang terjadi, di sisi lain untuk mencegah kesalahan manajemen (Arvidsson, 2010)social and ethical commitment of society has increased considerably, which puts pressure on companies to communicate information related to corporate social responsibility (CSR.

Pengungkapan corporate social responsibility dipengaruhi oleh pilihan, motif dan nilai-nilai manajer dan direktur yang memiliki keleluasaan total atas item apa saja yang akan diungkapkan dalam laporan CSR (Fuente, García-Sánchez, \& Lozano, 2017). Oleh karena itu dewan direksi bertanggungjawab terhadap manajemen resiko dan pelaporan perusahaan baik yang bersifat keuangan maupun non keuangan. Dengan adanya pengungkapan yang di laporkan perusahaan baik yang bersifat wajib atapun sukarela, akan mengurangi kekhawatiran terkait dengan resiko reputasi sebuah perusahaan dan keuangan yang terkait dengan masalah social dan lingkungan (Cheng \& Courtenay, 2006).

Tujuan pembangunan berkelanjutan menyediakan kerangka kerja dan alat untuk menganalisis resiko dan peluang bisnis untuk dapat menciptakan nilai perusahaan jangka Panjang. Dengan adanya kesadaran dewan direksi terhadap pengembangan pengetahuan terhadap SDGs, maka diharapkan SDGs menjadi bagian yang integral dari strategi bisnis perusahaan. Salah satu perubahan dalam tata kelola adalah kesempatan kepada kaum wanita untuk menduduki posisi pimpinan yaitu di dewan direksi perusahaan. Secara umum, setidaktidaknya terdapat 1 orang direktur wanita di jajaran dewan direksi pada perusahaan yang listing di bursa efek.

Menurut teori stakeholder, dewan direksi harus mengelola kepentingan dari banyak pihak, seperti investor, kreditor, pemasok, pemerintah dan masyarakat. Masalah pengungkapan menjadi salah satu yang di tuntut oleh stakeholder. Menurut beberapa penelitian, beberapa direktur kurang memiliki keahlian dalam masalah CSR (Manita, Bruna, Dang, \& Houanti, 2018)social and governance (ESG. Namun menurut penelitian yang dilakukan oleh Boulouta (2013) dan Harjoto et al (2015) dewan direksi perempuan lebih banyak kemungkinan lebih memahami CSR. Secara khusus, wanita memiliki karakteristik seperti lembut, empati dan suportif. Karena sifat tersebut, wanita lebih mementingkan kesejahteraan dan kepedulian terhadap lingkungan.

Kehadiran wanita dalam dewan direksi di perusahaan dapat meningkatkan kegiatan pengawasan manajemen, hal ini di karenakan adanya heterogenitas antara anggota dewan direksi, tim manajemen puncak dan CEO (Bear \& Post, 2010). Keanekaragaman gender tersebut dapat memberikan peran penting dalam menyelaraskan kepetingan manajerial dan pemegang saham. Pemangku kepentingan yang menginginkan perusahaan yang lebih bertanggungjawab terhadap lingkungan, maka direktur wanita akan lebih peka terhadap lingkungan. Dari uraian diatas maka dalat dirumuskan hipotesis pertama sebagai berikut :

H1: Terdapat pengaruh positif antara keberadaan wanita dalam dewan direksi terhadap pelaporan sustainability development goals (SDGs). 


\section{Pengaruh keberadaan dewan komisaris wanita dalam pengungkapan laporan sustainability development goals (SDGs).}

Salah satu bentuk pengawasan terhadap kinerja dewan direksi dalam menjalankan tugasnya adalah dengan dibentuknya dewan komisaris yang terdiri dari pihak eksternal (dewan komisaris independent) dan pihak internal yang merupakan perwakilan dari para pemegang saham perusahaan. Selain melakukan pengawasan dewan komisaris juga memiliki kewenangan untuk memberikan pendapat dan saran kepada dewan dewan direksi. Berdasarkan peraturan, rasio komisaris independent sekurang-kurangnya 30\% dari jumlah seluruh anggota dewan komisaris wajib diisi oleh anggota komisaris yang berasal dari luar perusahaan.

Dari perspektif teori agensi, perpaduan yang seimbang antara kemampuan dan pengalaman sangat penting bagi dewan direksi komisaris dalam melaksanakan fungsinya sebagai pihak yang melaksanakan fungsi pengawasan yang efektif terkait dengan jalannya perusahaan, menilai praktik manajemen dan mengevaluasi strategi manajemen. Dengan adanya Proporsi wanita yang tinggi pada dewan komisaris maka akan lebih transparan dan unggul dalam memantau kegiatan manajemen, seperti dengan adanya direksi wanita dalam komisaris akan menampilkan kinerja perusahaan yang baik dan mendorong lebih luasnya pengungkapan ke public (Jizi, 2017).

Perbedaan antara direksi wanita dan direksi pria terletak pada indikator efektivitas dewan. Dalam pengambilan keputusan, keberagaman dewan komisaris akan lebih cenderung menyediakan bentuk yang lebih baik, karena akan semakin banyak pendapat, kepercayaan, jaringan dan latar belakang untuk menyeimbangkan tujuan baik yang bersifak keuangan maupun non keuangan, serta keberagaman ini dapat menjawab tuntutan berbagai kelompok pemangku kepentingan yang saling bertentangan (Liao, Luo, \& Tang, 2014). Kehadiran wanita dalam dewan komisaris cenderung akan meningkatkan kualitas keputusan, Selain itu, dengan kehadiran wanita dalam dewan komisaris akan membuat diskusi menjadi lebih berkualitas karena umumnya wanita lebih memiliki demografi yang berbeda yang merefleksikan lingkungan social eonomi yang berbeda (Bowrin, 2013).

Selain itu, keberadaan dewan wanita juga membatu perusahaan dalam memahami lingkungan perusahaan dan menangani berbagai kebutuhan pemangku kepentingan. Hasil penelitian yang menyatakan bahwa ada pengaruh keberadaan wanita dalam dewan komisaris terhadap pengungkapan laporan sukarela sudah banyak tebukti. Diantaranya adalah penelitian yang dilakukan oleh Fernandez-Feijoo, Romero, \& RuizBlanco, 2014; Y. Li, Gong, Zhang, \& Koh, 2018; Jizi, 2017.

Oleh karena itu, keberadaan dewan komisaris wanita akan membentuk dimensi tata kelola yang baru, karena adanya keberagaman gender akan membuat perusahaan menjadi lebih efektif. Dengan adanya wanita dan pria, yang memiliki kepribadian yang berbeda dalam hal ketrampilan berkomunikasi, kepribadian dan komitmen, maka diharapkan perusahaan memiliki kemampuan yang lebih baik dalam merespon secara efektif terhadap pelaporan yang bersifat voluntary, salah satunya adalah pelaporan SDGs report. Sehingga dari uraian diatas, maka hipotesis kedua yang dirumuskan pada penelitian ini adalah sebagai berikut :

H2 : Terdapat pengaruh positif antara keberadaan wanita dalam dewan komisaris terhadap pelaporan sustainability development goals (SDGs).

Pengaruh Diversitas Gender Terhadap Pengungkapan Sustainability Development Goals 


\section{METODOLOGI PENELITIA N}

Penelitian ini adalah studi empiris dengan menggunakan model regresi yang menghubungkan antara pengungkapan SDGs dengan proporsi wanita dalam dewan direksi dan dewan komisaris.

\section{Populasi, Sampel dan Teknik Pengambilan Sampel}

Populasi penelitian ini adalah seluruh perusahaan yang terdaftar di Index Saham Syariah Indonesia (ISSI). Sementara sampelnya adalah perusahaan yang listing di ISSI selama 4 tahun secara berturut-turut dari tahun 2014-2017. Metode pemilihan sampel dilakukan dengan cara pusposive sampling dengan kriteri yang ditentukan sebagai berikut :

1. Perusahaan yang mempublikasikan laporan Sustainability Report dengan menggunakan pedoman Global Reporting Initiative (GRI).

2. Perusahaan yang mempublikasikan laporan keuangan selama tahun 2014-2017.

3. Perusahaan memiliki data varibel-variabel yang akan diteliti,

\section{Difinisi Operasonal dan Pengukuran Variabel}

\section{Pelaporan Sustainability Development Goals (SDGs)}

Variable dependen dalam penelitian ini adalah pengungkapan SDGs. Sustainability reporting merupakan publikasi informasi yang mencerminkan kinerja organisasi dalam dimensi ekonomi, social dan lingkungan (The Association Of Chartered Accountang, 2013). Variabel SDGs di ukur dengan Sustainability Report Disclosure Index (SDRI). Ada 2 jenis pengungkapan, yaitu standar umum dan standar khusus.

Perhitungan SRDI dilakukan dengan scoring, dimana skoring 1 akan diberikan jika satu item diungkapkan oleh perusahaan dan angka 0 (nol) diberikan ketika tidak ada item dalam standar yang diungkapkan. Setelah skor diberikan untuk semua item, maka skor tersebut akan di jumlahkan untuk memperoleh skor secara keseluruhan untuk setiap perusahaan. Rumus yang digunakan untuk perhitungan SRDI adalah :

$$
\mathrm{SRDI}=\frac{\mathrm{n}}{\mathrm{K}}
$$

Dimana :

SRDI : Sustainability Report Disclosue Index perusahaan

$\mathrm{n} \quad$ : jumlah item yang diungkapkan perusahaan

k : jumlah item yang diharapkan diungkapkan

\section{Proporsi Jumlah Wanita Dalam Dewan Direksi}

Menurut Undang-undang no 40/2007 pasal 97 yang dinamakan dewan direksi adalah pihak yang memiliki wewenang dan tanggungjawab untuk mengelola perusahaan untuk kepentingan perusahaan. Proporsi jumlah direksi wanita dalam dewan direksi di ukur dengan instrument yang di rekomendasikan Teachman (1980), yang telah banyak diadopsi untuk mengukur berbagai dimensi keberagaman demografi, termasuk 
keragaman gender ((J. Li et al., 2017). Formula yang digunakan adalah dengan membagi jumlah dewan direksi wanita dengan jumlah total dewan direksi perusahaan tersebut.

$$
\text { GENDER_DIR }=\frac{\text { jumlah dewan direksi perempuan }}{\text { jumlah dewan direksi }}
$$

\section{Proporsi Jumlah Wanita Dalam Dewan Komisaris}

Dewan komisaris adalah salah satu unsur dari good corporate governance yang memiliki peran penting untuk mengawasi kinerja dewan direksi dan pihak manajemen perusahaan. Pengukuran yang digunakan untuk mengukur proporsi jumlah wanita dewan komisaris dalam suatu perusahaan menggunakan formula yang sama ketika mengukur proporsi jumlah wanita dalam dewan komisaris.

$$
\text { GENDER_KOM }=\frac{\text { jumlah dewan komisarisp erempuan }}{\text { jumlah dewank omisaris }}
$$

\section{Variabel Kontrol}

\section{Ukuran perusahaan}

Penelitian ini menggunakan variable control ukuran perusahaan dikarenakan perusahaan yang relative besar dapat meyebabkan lebih banyak pencemaran lingkungan dibandingkan perusahaan kecil. Namun bisa juga perusahaan besar juga akan memiliki lebih banyak sumberdaya untuk menangani permasalahn lingkungan dbandingkan perusahaan kecil. Ukuran perusahaan dilihat dari besarnya total asset yang dimiliki perusahaan dan total asset ini akan dinilai dengan cara menggunakan logaritma dari total asset perusahaan.

\section{Leverage}

Rasio leverage yang tinggi akan mendorong perusahaan untuk mengungkapkan informasi sebanyakbanyaknya kepada stakeholder. Hal ini dimaksudkan untuk dapat mengurangi biaya monitoring atau pengawasan. Leverage yang semakin tinggi akan memungkinkan perusahaan untuk mengungkapkan informasi yang lebih luas dibandingkan dengan perusahaan dengan leverage yang kecil. Pengukuran leverage di ukur dengan menggunakan debt to equity ratio (DER)

\section{Profitabilitas}

Perusahaan dengan tingkat profitabilitas yang tinggi cenderung untuk mengungkapkan lebih banyak informasi atau pengungkapan, karena perusahaan yang memiliki kemampuan menghasilkan laba lebih besar, biasanya juga akan memiliki lebih banyak dana yang digunakan untuk pengungkapan baik secara sukarela maupun yang bersifat wajib. Variabel ini diukur dengan menggunakan ROA (return on asset). 


\section{HASIL DAN PEMBAHASAN}

\section{Hasil Penelitian}

Penelitian ini dilakukan pada perusahaan yang listing di ISSI (Indeks Saham Syariah Indonesia) yang secara konsisten melaporkan laporan keuangan pada tahun 2013 sampai dengan 2017. Berdasarkan metode purposive sampling, maka jumlah sampel yang digunakan dalam penelitian ini adalah sebanyak 10 perusahaan sampel.

\section{Pembahasan}

\section{Pengaruh Proporsi dewan direksi wanita terhadap Pengungkapan SDGs}

Berdasarkan hasil pengujian hipotesis diperoleh bukti bahwa proporsi wanita dalam dewan direksi tidak berpengaruh terhadap besarnya pengungkapan SDGs. Hal ini dapat dilihat dari data yang diperoleh bahwa nilai t hitung sebesar 1,236 dengan signifikansi 0,223, pada tingkat signifikansi 0,05 atau 5\%. Dengan demikian hipotesis pertama menyatakan bahwa proporsi wanita dalam dewan direksi tidak berpegaruh signifikan terhadap besarnya pengungkapan laporan SDGs, yang berarti bahwa hipotesis pertama $(\mathrm{H} 1)$ di tolak.

Hal ini berarti membuktikan bahwa keberadaan direktur wanita dalam dewan direksi tidak mempengaruhi pengungkapan SDGs yang dilakukan oleh perusahaan yang listing di ISSI. Hasil penelitian ini mendukung penelitian yang telah dilakukan oleh Manita, Bruna, Dang, \& Houanti (2018)social and governance (ESG dan Boulouta (2013) yang menyatakan bahwa keberadaan direktur wanita memiliki dampak positif terhadap kinerja social perusahaan, tetapi memiliki hubungan yang lemah. Hasil ini juga sesuai dengan penelitian yang dilakukan oleh Byron \& Post (2016) yang juga menemukan hubungan yang lemah atau tidak ada pengaruh yang signifikan keberadaan direksi perempuan terhadap pengungkapan CSR.

Secara teori hubungan antara keberadaan direksi wanita dengan besarnya pengungkapan SDGs adalah dengan adanya keberadaan direksi wanita maka akan dapat meningkatkan transparansi dan etika kepatuhan perusahaan terhadap aturan yang mengatur terkait dengan pengungkapan informasi kepada stakeholder. Namun, hasil penelitian membuktikan bahwa tidak ada pengaruhnya keberadaan direksi wanita terhadap pengungkapan SDGs perusahaan. Hal ini juga didukung data sampel yang menunjukkan masih rendahnya keberadaan wanita dalam dewan direksi. Data menunjukkan keberadaan wanita dalam dewan direksi rata-rata masih 11\%, jauh dibawah 50\%.

Rendahnya proporsi keberadaan wanita dalam dewan direksi akan mengurangi kemampuan wanita untuk mempengaruhi dan mendorong adanya perubahan. Jadi hal ini akan bisa berdampak pada pengungkapan SDGs yang menyebabkan pengungkapan tidak efektif atau bahkan memberikan kesan negative (Manita et al., 2018)social and governance (ESG. Keberadaan wanita dalam dewan direksi yang hanya berjumlah tidak lebih dari 3 orang menyebabkan tidak adanya kemampuan untuk mempengaruhi dewan direksi. Dengan demikian, tingkat feminisme yang rendah dalam dewan direksi dapat menyebabkan efek negative pada keragaman kognitif (terkait dengan berbagi informasi dan pengetahuan yang heterogen). jika wanita yang mendominasi dalam suatu organisasi maka akan tercipta adanya keragaman pemikiran, sehingga akan lebih banyak alternative keputusan yang dapat diambil. 
Hasil yang menyatakan bahwa tidak ada pengaruh keberadaan dewan direksi wanita terhadap pengungkapan SDGs bisa juga disebabkan karena peranan wanita dalam dewan direksi hanya bersifat pelengkap. Perusahaan ingin menunjukkan kepada stakeholder bahwa perusahaan peduli terhadap persamaan gender. Mengutip penelitian Seierstad et al (2017) peran direktur wanita dalam dewan direksi adalah sangat penting, hal ini disebabkan karena alasan keadilan. Alasan ini berfokus pada adanya kesetaraan gender antara direksi wanita dan direksi laki-laki. Sehingga dengan demikian citra perusahaan menjadi lebih baik dimata stakeholder.

Menurut penelitian yang dilakukan oleh Manita et al., (2018)social and governance (ESG keberadaan jumlah wanita dalam dewan direksi dua, tiga atau lebih cenderung akan mengungkapkan laporan sukarela lebih tinggi, hal ini dikarenakan adanya pengaruh feminism yang lebih menyukai transparansi, keterbukaan dan komitmen terhadap corporate social responsibility. Jadi, ketika dua atau lebih wanita terlibat dalam pengambilan keputusan yang strategis, mereka akan bertindak sebagai minoritas aktif, dapat mempengaruhi peraturan, prosedur dan praktik.

Masih mengutip dari penelitian Manita et al., (2018)social and governance (ESG sedikitnya keberadaan wanita dalam dewan direksi disebabkan karena adanya kekhawatiran transparansi yang berlebihan kepada pemegang saham karena sifat feminim dewan direksi wanita. Sehingga, ada pembatasan wanita dalam menduduki jabatan direksi dalam perusahaan.

Dalam penelitian yang dilakukan oleh Feijoo, et al, (2014) peranan direksi wanita dalam pengungkapan pelaporan SDGs adalah ketika jumlah direksi wanita sekurang-kurangnya adalah 3 orang. Dalam data penelitian menunjukkan bahwa rata-rata jumlah dewan direksi wanita adalah tidak lebih dari 3 orang. Hanya ada satu perusahaan yang memiliki dewan direksi wanita 4 orang yaitu PT Unilever Indonesia, Tbk. Sehingga hal ini menyebabkan peran wanita dalam dewan direksi pada perusahaan yang listing di ISSI tidak dapat mempengaruhi besarnya pengungkapan SDGs, dikarenakan jumlah direksi wanita yang masih sangat minim.

\section{Pengaruh Proporsi dewan komisaris wanita terhadap Pengungkapan SDGs}

Hasil penelitian menunjukkan bahwa hipotesis kedua yang menyatakan bahwa keberadaan dewan komisaris wanita berpengaruh terhadap pengungkapan laporan SDGs terbukti dan berpengaruh signifikan. Keberadaan dewan komisaris wanita ternyata membuat perusahaan mengungkapkan lebih banyak pengungkpakan SDGs dalam laporannya. hal ini disebabkan karena wanita lebih bersikap hati-hati dalam pengambilan keputusan dan lebih banyak untuk menghindari resiko. Oleh karena itu dewan komisaris wanita akan melakukan pengawasan yang lebih teliti dan penuh dengan unsur kehati-hatian di bandingkan direktur komisaris pria. Dengan keberadaan wanita dalam dewan komisaris, dapat membantu dewan direksi dalam mengambil sebuah keputusan yang lebih baik dan memiliki resiko yang rendah (Sudana \& Arlindania W, 2011)

Sesuai dengan penelitian yang dilakukan oleh Ferreira, (2009), keberadaan pemimpin wanita yang kolaboratif dapat menciptakan keuntungan dinamis karena seorang wanita akan lebih intens dalam mendengarkan pendapat, inovasi dan keluhan karyawan dan dukungan sosial. Pemimpin wanita juga lebih mempunyai kmitmen yang kuat untuk melakukan kegiatan amal di lingkungan sekitar.

Pengaruh Diversitas Gender Terhadap Pengungkapan Sustainability Development Goals 
Penelitian ini sejalan dengan peneliian yang telah dilakukan oleh Hussain \& Rigoni, (2018) yang menyatakan bahwa independent direktur memiliki peran penting dalam mendorong keberlanjutan kinerja, keberadaan wanita dalam dewan direksi komisari akan dapat meningkatkan kinerja yang berkelanjutan serta adanya sustainability committee memainkan peran positif yang substansial dalam meningkatkan kinerja lingkungan dan social. Sedangkan penelitian yang dilakukan oleh Kassinis,et al (2016) dengan sampel perusahaan di Amerika Serikat selama 5 periode menyatakan bahwa keragaman gender dalam dewan komisaris akan memiliki efek langsung dan terukur pada praktik kelestarian lingkungan perusahaan.

\section{Pengaruh Variabel Kontrol Terhadap Pengungkapan SDGs}

Dari hasil penelitian menunjukkan bahwa hanya variable size saja yang berpengaruh terhadap pengungkapan Sustainability Development Goals. Sedangkan 2 variabel lainnya yaitu variable profitabilitas dan leverage tidak mempengaruhi pengungkapan SDGs. Semakin besar ukuran perusahaan maka semakin mendorong perusahaan untuk mengungkapkan semua item dalam SDGs. Hal ini dilakukan salah satunya adalah untuk mengurangi resiko dan tekanan dari masyarakat. Selain itu hal dengan pengungkapan tersebut dapat mengurangi biaya agensi.

\section{KESIMPULAN, KETERBATASAN DAN SARAN}

Kesadaran masyarakat akan semakin rusaknya lingkungan yang disebabkan karena kegiatan industry perusahaan-perusahaan besar, menjadikan masyarakat membutuhkan informasi mengenai sejauhmana perusahaan bertanggungjawab atas kerusakan tersebut. Krisis ekologi ini mendorong keprihatinan dari berbagai negara di dunia. Salah satu upayanya adalah dengan merumuskan Sustainability Development Goals yang diharapkan dapat membantu dalam mengatasi kemiskinan, kesenjangan dan perubahan iklim dalam bentuk aksi nyata. Representasi wanita dalam kepemimpinan suatu perusahaan dapat menjadi salah satu pendorong perusahaan untuk dapat lebih peduli terhadap pengungkapan sukarela. Hal ini disebabkan karena sifat kepeminpinan wanita yang lebih proaktif dalam bekerjasama, berhati-hati dalam pengambilan keputusan dan lebih sensitive terhadap masalah lingkungan.

Hasil penelitian menunjukkan bahwa kepemimpinan direksi pada perusahaan sampel tidak berpengaruh terhadap pengungkapan SDGs, salah satunya disebabkan karena masih rendahnya representasi wanita dalam dewan direksi, dimana rata-rata jumlah dewan direksi wanita tidak lebih dari 3 orang. Sedangkan keberadaan dewan komisaris terbukti dapat mendorong perusahaan untuk mengungkapkan SDGs lebih luas. Hal ini disebabkan karena dewan komisaris wanita memiliki peran penting dalam mendorong keberlanjutan kinerja dan keragaman gender dapat memiliki efek langsung dan terukur pada praktik kelestarian lingkungan perusahaan.

Keterbatasan dari penelitian ini adalah masih rendahnya adjusted $\mathrm{R}$ square yang hanya 30,3\%. Hal ini berarti masih ada variable lain yang dapat mempengaruhi pengungkapan SDGs. Sebaiknya peneliti selanjutnya mempertimbangkan dan menambahkan variable lain dalam pengungkapan SDGs dan memperluas sampel dan periode pengamatan. 


\section{REFERENSI}

ACCA. The Association of Chartered Certified Accountants. 2013. The Business Benefits Of Sustainability Reporting in Singapore. Singapore.

Adams, C. A. (2017). The Sustainable Development Goals, integrated thinking and the integrated report. Integrated Reporting (IR).

Aguilera, R. V, Williams, C. A., Conley, J. M., \& Rupp, D. E. (2006). Corporate Governance and Social Responsibility : A Comparative Analysisi of The UK and The US. Journal Compilation, 14(3), 147-158.

Arvidsson, S. (2010). Communication of Corporate Social Responsibility: A Study of the Views of Management Teams in Large Companies. Journal of Business Ethics, 96(3), 339-354.

Badan Pusat Statistik (BPS). (2014). Kajian Indikator Sustainable Development Goals (SDGs). Retrieved from https://media.neliti.com/media/publications/48852-ID-kajian-indikator-sustainable-developmentgoals.pdf

Bear, S., \& Post, C. (2010). The Impact of Board Diversity and Gender Composition on Corporate Social Responsibility and Firm Reputation, 207-221.

Bowrin, A. R. (2013). Corporate social and environmental reporting in the Caribbean. Social Responsibility Journal, 9(2), 259-280.

Byron, K., \& Post, C. (2016). Women on Boards of Directors and Corporate Social Performance : A Meta-Analysis. An International Review, 1-15.

carter, david A; Simkins, Betty ; Simpon, G. (2003). Corporate Governance, Board Diversity , and Firm Value. Economics Bulletin, 38, 33-53.

Cheng, E. C. M., \& Courtenay, S. M. (2006). Board composition, regulatory regime and voluntary disclosure. International Journal of Accounting, 41(3), 262-289.

Cormier, D., Ledoux, M. J., \& Magnan, M. (2011). The informational contribution of social and environmental disclosures for investors. Management Decision, 49(8), 1276-1304.

Dalziel, H. and. (2003). Boards Of Directors And Firm Performance: Integrating Agency And Resource Dependence Perspectives, 28(3), 383-396.

David Evans. (2013). Aspiring to leadership ... a woman's world? An example of developments in France. Cross Cultural Management : An International Journal Article, 17(4), 347-367.

De Celis, I. L. R., Velasco-Balmaseda, E., De Bobadilla, F. S., Alonso-Almeida, M. D. M., \& Intxaurburu-Clemente, G. (2015). Does having women managers lead to increased gender equality practices in corporate social responsibility? Business Ethics, 24(1), 91-110.

Elliot, S. (2013). A Transdisciplinary Exploratory Model of Corporate Responses to the Challenges of Environmental Sustainability. Business Strategy and the Environment, 22(4), 269-282.

Fernandez-Feijoo, B., Romero, S., \& Ruiz-Blanco, S. (2014). Women on boards: Do they affect sustainability reporting? Corporate Social Responsibility and Environmental Management, 21(6), 351-364.

Ferreira, D. (2009). Women in the Boardroom and Their Impact on Governance and Performance. Journal of 
Financial Economics, 94, 291-309.

Fuente, J. A., García-Sánchez, I. M., \& Lozano, M. B. (2017). The role of the board of directors in the adoption of GRI guidelines for the disclosure of CSR information. Journal of Cleaner Production, 141, 737-750.

Global Reporting Initiative. (2013). Pedoman Pelaporan Keberlanjutan G4. Global Reporting Initiative. Retrieved from www.globalreporting.org

Hadya, R., \& Susanto, R. (2018). Model Hubungan Antara Keberagaman Gender, Pendidikan Dan Nationality Dewan Komisaris Terhadap Pengungkapan Corporate Social Responsibility. Jurnal Benefita, 3(2), 149.

Hillman, A. J., Cannella Jr., A. A., \& Harris, I. C. (2002). Women and racial monorities in the boardroom: how do they differ? Journal of Management, 28(6), 747-763.

Huse, M., Nielsen, S. T., Marie, I., \& Fafo, H. (2008). Women and employee-elected board members and their contributions to board control tasks. Journal of Business Ethics, 18(89), 581-597.

Hussain, N., \& Rigoni, U. (2018). Corporate Governance and Sustainability Performance: Analysis of Triple Bottom Line Performance, 411-432.

Jensen, M. C., \& Meckling, W. H. (1976). Theory of Firm : Managerial Behavior, Agency Cost and Ownership Structure. Journal of Financial Economics, 3(4), 305-360.

Jizi, M. (2017). The Influence of Board Composition on Sustainable Development Disclosure. Business Strategy and the Environment, 26(5), 640-655.

Kassinis, G., Panayiotou, A., Dimou, A., \& Katsifaraki, G. (2016). Gender and Environmental Sustainability: A Longitudinal Analysis. Corporate Social Responsibility and Environmental Management, 23(6), 399-412.

Kim, H. (2013). Glass Fence Thicker Than Glass Ceiling : The Puzzling Gaps of Women's Leadership in Korea. In Culture and Gender in Leadership (pp. 253-274).

Levi, M., Li, K., \& Zhang, F. (2014). Director gender and mergers and acquisitions. Journal of Corporate Finance, 28, 185-200.

Li, J., Zhao, F., Chen, S., Jiang, W., Liu, T., \& Shi, S. (2017). Gender Diversity on Boards and Firms' Environmental Policy. Business Strategy and the Environment, 26(3), 306-315.

Li, Y., Gong, M., Zhang, X. Y., \& Koh, L. (2018). The impact of environmental, social, and governance disclosure on firm value: The role of CEO power. British Accounting Review, 50(1), 60-75.

Liao, L., Luo, L., \& Tang, Q. (2014). Gender diversity , board independence, environmental committee and greenhouse gas disclosure q. The British Accounting Review, 1-16.

Low, D. C. M., Roberts, H., \&Whiting, R. H. (2015). Paci fi c-Basin Finance Journal Board gender diversity and fi rm performance : Empirical evidence from Hong Kong , South Korea, Malaysia and Singapore. Pacific-Basin Finance Journal.

Luckerath-Rovers. (2010). Women On Board And Firm Performance, Erasmus University Rotterdam April 2010, 4089144(April).

Manita, R., Bruna, M. G., Dang, R., \& Houanti, L. (2018). Board gender diversity and ESG disclosure: evidence from the USA. Journal of Applied Accounting Research, 19(2), 206-224.

Martinez, maria consuelo pucheta, Bel-oms, I., \& Sempere, G. O. (2018). The Association between board gender 
diversity and financial reporting quality,corporate performance and corporate social responsibility disclosure :A literature review. Emerald Insight, 0-27.

Martínez, M. C. P., Oms, I. B., \& Olcina-Sempere, G. O. (2018). The association between board gender diversity and financial reporting quality, corporate performance and corporate social responsibility disclosure: A literature review. emeraldinsight (Vol. 39).

Mazaya, Viky. (2014). Kesetaraan Gender Dalam Perspektif Sejarah Islam, SAWWA : Jurnal Studi Gender, 9(April), 323-344.

Nielsen, S., \& Huse, M. (2010). The contribution of women on boards of directors: Going beyond the surface. Corporate Governance: An International Review, 18(2), 136-148.

Nosratollah, M., \& Aryan, A. (2016). Designing effective female leadership model in governmental organizations. African Journal of Business Management, 7(32), 3186-3195.

Robinson, G., \& Dechant, K. (1997). Building a business case for diversity. Academy of Management Perspectives, 11(3), 21-31.

Seierstad, C., Warner-Søderholm, G., Torchia, M., \& Huse, M. (2017). Increasing the Number of Women on Boards: The Role of Actors and Processes. Journal of Business Ethics, 141(2), 289-315.

Situmorang, N. Z. (2011). Gaya Kepemimpinan Perempuan. In Psikologi, Ekonomi, Sastra, Arsitektur \& Sipil (pp. 129-135).

Solimene, S., Coluccia, D., \& Fontana, S. (2017). Gender Diversity on Corporate Boards: An Empirical Investigation of Italian Listed Companies. Ssrn, 3, 1-7.

Sudana, I. M., \& Arlindania W, P. A. (2011). Corporate Governance dan Pengungkapan Corporate Social Responsibility pada Perusahaan Go-Public di Bursa Efek Indonesia. Jurnal Manajemen Teori Dan Terapan, 4(1), 37-49.

Tahir, R. (2017). Women on Corporate Boards: The New Zealand Perspective (pp. 473-483).

Terjesen, S., \& Singh, V. (2008). Female presence on corporate boards: A multi-country study of environmental context. Journal of Business Ethics, 83(1), 55-63.

Xiao, Y., Norris, C. B., Lenzen, M., Norris, G., \& Murray, J. (2017). How Social Footprints of Nations Can Assist in Achieving the Sustainable Development Goals. Ecological Economics, 135, 55-65.

Yasser, Q. R., Al Mamun, A., \& Ahmed, I. (2017). Corporate Social Responsibility and Gender Diversity: Insights from Asia Pacific. Corporate Social Responsibility and Environmental Management, 24(3), 210-221.

Undang-undang no 40/2007

Pengaruh Diversitas Gender Terhadap Pengungkapan Sustainability Development Goals 


\section{LAMPIRAN}

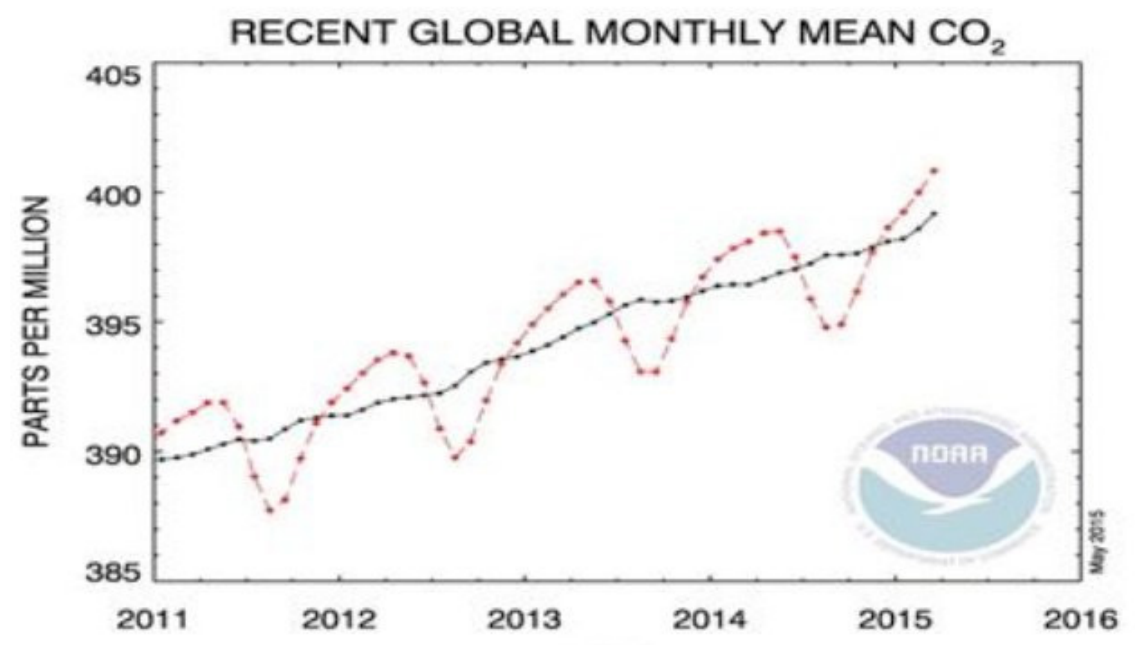

Sumber : National Oceanic and Atmospheric Administration

Gambar 1.

Grafik peningkatan CO2 Pada Lapisa Atmosfer

Tabel 1. Ringkasan Uji Asumsi Klasik

\begin{tabular}{|c|c|c|}
\hline Uji Multikolonieritas & Tolerance & VIF \\
\hline - Gender_Dir & 0.767 & 1.303 \\
\hline - Gender_Kom & 0.895 & 1.117 \\
\hline \multicolumn{3}{|l|}{ Variabel Kontrol } \\
\hline - Leverage & 0.355 & 2.817 \\
\hline - Profitabilitas & 0.654 & 1.530 \\
\hline - Size & 0.394 & 2.540 \\
\hline Uji Heteroskedastisitas (Glejser test) & Sig. t-test & \\
\hline - Gender_Dir & 0.517 & \\
\hline - Gender_Kom & 0.171 & \\
\hline \multicolumn{3}{|l|}{ Variabel Kontrol } \\
\hline - Leverage & 0.146 & \\
\hline - Profitabilitas & 0.687 & \\
\hline - Size & 0.095 & \\
\hline Durbin-Watson test & 1.862 & \\
\hline \multicolumn{3}{|l|}{ Normality Test } \\
\hline - kolmogorov- Smirnov test & 0,623 & \\
\hline - $\quad$ Adj R Square & 0.303 & \\
\hline$N=50$ & & \\
\hline
\end{tabular}


Tabel 2 Ringkasan Hasil Pengujian Hipotesis Parameter Individual (Uji t)

Variabel bebas dan kontrol

\begin{tabular}{lccc}
\hline Pengujian hipotesis & Coefficient & t value & Sign \\
\hline - Gender_Dir & 0.180 & 1.23 & 0.223 \\
- Gender_Kom & 0.302 & 2.244 & 0.030 \\
- Leverage & 0.350 & 1.635 & 0.109 \\
- Profitabilitas & 0.251 & 1.590 & 0.119 \\
- Size & 0.312 & 2.188 & 0.041 \\
\hline
\end{tabular}

Sumber : Data sekunder yang diolah (2019) 